\title{
FAKTOR-FAKTOR YANG MEMPENGARUHI PASANGAN REMAJA USIA 13 - 22 TAHUN UNTUK MELAKUKAN SEX BEBAS DI KAWASAN TRETES KECAMATAN PRIGEN KABUPATEN PASURUAN
}

\author{
Iis Fatimawati, S.Kep,Ns.,M.Kes \\ M. Rijal Febrianto
}

Stikes Majapahit Mojokerto. J1. Raya Gayaman Km.2 Mojoanyar Mojokerto, Email : $\underline{\text { iis.fatimawati@gmail.com }}$

\begin{abstract}
Adolescence is a period of transition from child to adulthood. Many problems experienced by adolescents in this biological transition, for example is free sex. The purpose of this study was to determine the factors that influence teenage couples aged 13-22 years for free sex in the districts Tretes Prigen Pasuruan regency. This study used a cross sectional analytic design. Independent variable in this study is the family factor, sex education, and environment. Dependent Variabel is free sex. The sample was mostly couples teenager in Tretes Pasuruan District Prigen that totaling 34 people. Sampling technique that is accidental sampling. This study was conducted in June 2014. Results showed the majority of family factors (55.9\%) is less. Factors sex education the majority (67.6\%) is less. Environmental factors most (61.8.\%) Is less. Teen couple who are free sex is majority (64.7\%). Analysis using chi square test showed association of family factors, environmental factors, and the factor of sex education to teen couple sex free.Need for Sex explanation that correct and proper manner that is based on religious values, culture and ethics, so the teenager will avoid that are negative things and reprehensible associated with problem-free sex.
\end{abstract}

Keywords: adolescent, family, sex education, environment, free sex

\section{Pendahuluan}

Masa remaja adalah masa transisi dari anak-anak menuju dewasa. Banyak masalah yang dialami oleh para remaja dalam masa transisi biologis ini, salah satunya adalah masalah sex bebas. Free sex atau seks bebas menjadi hal yang sangat biasa bagi kalangan remaja saat ini. Tanpa merasa malu mereka meminta pasangannya untuk melakukan hal itu, hal yang sebenarnya dianggap tabu oleh masyarakat sekitar. Bukan hanya wanita dewasa (> 20 tahun) saja yang melakukannya, namun sekarang kalangan

Jurnal Ilmu Kesehatan Vol.2 No. 2 Mei 2014 remaja sudah melakukannya walaupun hanya satu kali. Kejadian ini menimpa remaja-remaja yang justru masih sekolah SMP dan SMA yang bukan hanya keberadaannya di kota-kota besar saja melainkan sudah sampai ke pelosok desa (BKKBN, 2009).

Perilaku seks bebas didunia saat ini terus mengalami peningkatan yang sangat pesat. Pichkel melaporkan bahwa di AS $25 \%$ anak perempuan berusia 17 tahun dan anak laki-laki usia 17 tahun telah berhubungan intim. Di Inggris lebih dari $20 \%$ anak perempuan berusia 16 tahun rata-rata telah berhubungan seks dengan tiga laki-laki (Jurnal Medika, 2010). 
Fenomena seks bebas di Indonesia semakin memprihatinkan. Data dari hasil survey (Komisi Perlindungan Anak Indonesia) KPAI di 33 provinsi dari Januari sampai Juli 2013 menunjukkan $62,7 \%$ remaja SMP tidak perawan. Badan koordinasi keluarga berencana nasional BKKBN tahun 2012 menyebutkan hal yang sama bahwa terdapat $22,6 \%$ remaja menganut seks bebas.

Faktor penyebab seks bebas antara lain adalah situasi yang mendukung dimana ketika pasangan muda mudi tersebut mengambil tempat untuk bertemu dan berkencan di tempat yang sepi, penanaman nilai dan norma agama yang kurang tepat juga merupakan penyebab seks bebas dimana sebagian orang tua kurang menanamkan rasa takut kepada Tuhan (Panjaitan, 2007). Fenomena yang saya temui di kawasan Tretes, awalnya para remaja bertemu untuk mencari tempat pacaran yang sepi karena jika pacaran dirumahnya takut dimarahi sama orang tuanya, akhirnya mereka memutuskan untuk menyewa vila di kawasan Tretes. Mereka beranggapan vila merupakan tempat yang sepi, enak dibuat pacaran, dan melakukan hubungan sex. Dorongan perasaan dan keinginan seks sual cukup pesat pada remaja dapat mengakibatkan remaja menjadi rentan terhadap pengaruh buruk dari luar yang mendorong timbulnya perilaku seksual yang berisiko tinggi.

Untuk mengatasi masalah-masalah ini diperlukan adanya pemahaman dan penerangan tentang seks secara benar dan tepat yang dilandasi oleh nilai-nilai agama, budaya dan etika yang ada dimasyarakat. Penyuluhan dan penerangan tentang seks harus dilandaskan pada ilmu pengetahuan dan nilai-nilai agama, sehingga seorang remaja akan mendapatkan informasi yang benar dan tepat dengan berlandaskan pada nilai-nilai agama dan keimanan yang kuat sehingga seorang remaja dapat terhindar dari hal-hal yang negatif dan tercela terkait dengan masalah seks. Untuk itu pendidikan seks dan bimbingan sangat diperlukan.

\section{Bahan dan Metode}

Jenis penelitian dalam penelitian ini menggunakan analitik korelasional dengan desain analitik croos sectional. Variabel independent dalam penelitian ini adalah faktor-faktor yang mempengaruhi seks bebas. Yaitu meliputi Faktor keluarga, Faktor pendidikan seks dalam keluarga, Faktor lingkungan. Variabel dependent dalam penelitian ini adalah sex bebas. Populasi dalam penelitian ini adalah semua pasangan remaja di Kawasan Tretes Kecamatan Prigen Kabupaten Pasuruan. Sampel yang digunakan dalam penelitian ini adalah sebagian pasangan remaja di Kawasan Tretes Kecamatan Prigen Kabupaten Pasuruan yang berjumlah 34 orang.

Pengambilan sampling dalam penelitian ini adalah non probability sampling dengan jenis accidental sampling yaitu cara pengambilan sampling yang dilakukan dengan kebetulan bertemu (Hidayat, 2009).

Penelitian ini dilaksanakan di Kawasan Tretes Kecamatan Prigen Kabupaten Pasuruan dalam waktu 2 minggu pada bulan Juni 2014.

\section{Hasil}

a. Karakteristik responden berdasarkan umur

\begin{tabular}{cccc}
\hline No & $\begin{array}{c}\text { Umur } \\
\text { (Tahun) }\end{array}$ & Frekuensi & Persentase (\%) \\
\hline 1 & $13-15$ & 0 & 0 \\
2 & $16-20$ & 9 & 26,5 \\
3 & $21-22$ & 25 & 73,5 \\
\hline & Total & 34 & 100 \\
\hline
\end{tabular}

Berdasarkan tabel 4.1. menunjukkan bahwa sebagian besar responden berumur 21-22 tahun sebanyak 25 orang $(73,5 \%)$. 
b. Karakteristik responden berdasarkan pendidikan

\begin{tabular}{cccc}
\hline No & Pendidikan & Frekuensi & $\begin{array}{c}\text { Persentase } \\
(\%)\end{array}$ \\
\hline 1 & $\begin{array}{c}\text { Pendidikan dasar } \\
\text { (SD, SMP) }\end{array}$ & 0 & 0 \\
& $\begin{array}{c}\text { Pendidikan } \\
2\end{array}$ & 7 & 20,6 \\
3 & menengah (SMA) & 7 & 79,4 \\
\hline & Pendidikan tinggi & 27 & 100 \\
\hline
\end{tabular}

Berdasarkan tabel 4.2. menunjukkan bahwa hampir seluruhnya responden berpendidikan tinggi (PT) sebanyak 27 orang $(79,4 \%)$.

c. Karakteristik responden berdasarkan pekerjaan

\begin{tabular}{|c|c|c|c|}
\hline No & Pekerjaan & Frekuensi & $\begin{array}{c}\text { Persentase } \\
(\%)\end{array}$ \\
\hline 1 & Bekerja & 27 & 79,4 \\
\hline 2 & $\begin{array}{l}\text { Tidak } \\
\text { bekerja }\end{array}$ & 7 & 20,6 \\
\hline & Total & 34 & \\
\hline
\end{tabular}

Berdasarkan tabel 4.3. menunjukkan bahwa hampir seluruhnya responden bekerja sebanyak 27 responden $(79,4 \%)$.

d. Karakteristik responden berdasarkan informasi tentang sex bebas

\begin{tabular}{clcc}
\hline No & Informasi & Frekuensi & $\begin{array}{c}\text { Persentase } \\
(\%)\end{array}$ \\
\hline 1 & Pernah & 8 & 23,5 \\
2 & $\begin{array}{l}\text { Tidak } \\
\text { pernah }\end{array}$ & 26 & 76,5 \\
\hline & Total & 34 & 100 \\
\hline
\end{tabular}

Berdasarkan tabel 4.4. menunjukkan bahwa hampir seluruhnya responden tidak pernah mendapat informasi sebanyak 26 responden $(76,5)$.

e. Karakteristik responden berdasarkan pernah mendapatkan sumber informasi

\begin{tabular}{clcc}
\hline No & $\begin{array}{c}\text { Sumber } \\
\text { Informasi }\end{array}$ & Frekuensi & $\begin{array}{c}\text { Persentase } \\
(\%)\end{array}$ \\
\hline 1 & Petugas & & \\
kesehatan & 0 & 0 \\
2 & Majalah & 0 & 0 \\
3 & $\begin{array}{l}\text { Radio/TV, } \\
\text { internet }\end{array}$ & 8 & 100 \\
4 & Lain-lain & 0 & 0 \\
\hline & Total & 8 & 100 \\
\hline
\end{tabular}

Berdasarkan tabel 4.5. menunjukkan bahwa seluruhnya responden mendapatkan sumber informasi dari radio/TV/internet sebanyak 8 responden $(100 \%)$.

f. Karakteristik responden berdasarkan status

\begin{tabular}{cccc}
\hline No & Status & Frekuensi & $\begin{array}{c}\text { Persentase } \\
(\%)\end{array}$ \\
\hline 1 & Sekolah & 7 & 20,6 \\
2 & Kerja & 27 & 79,4 \\
\hline & Total & 34 & 100 \\
\hline
\end{tabular}

Berdasarkan tabel 4.6. menunjukkan bahwa hampir seluruhnya responden bekerja sebanyak 27 responden $(79,4)$.

g. Faktor keluarga

\begin{tabular}{cccc}
\hline No & $\begin{array}{c}\text { Faktor } \\
\text { keluarga }\end{array}$ & Frekuensi & $\begin{array}{c}\text { Persentase } \\
(\%)\end{array}$ \\
\hline 1 & Baik & 4 & 11,8 \\
2 & Cukup & 11 & 32,4 \\
3 & Kurang & 19 & 55,9 \\
\hline & Total & 34 & 100 \\
\hline
\end{tabular}

Berdasarkan 4.7. diketahui bahwa sebagian besar faktor keluarga adalah kurang sebanyak 19 orang $(55,9 \%)$.

h. Faktor pendidikan seks

\begin{tabular}{cccc}
\hline No & $\begin{array}{c}\text { Faktor } \\
\text { pendidikan } \\
\text { seks }\end{array}$ & Frekuensi & $\begin{array}{c}\text { Persentase } \\
(\%)\end{array}$ \\
\hline 1 & Baik & 4 & 11,8 \\
2 & Cukup & 7 & 20,6 \\
3 & Kurang & 23 & 67,6 \\
\hline & Total & 34 & 100 \\
\hline
\end{tabular}

Berdasarkan 4.8. diketahui bahwa sebagian besar faktor pendidikan seks adalah kurang sebanyak 23 orang $(67,6 \%)$.

i. Faktor lingkungan

\begin{tabular}{cccc}
\hline No & $\begin{array}{c}\text { Faktor } \\
\text { lingkungan }\end{array}$ & Frekuensi & $\begin{array}{c}\text { Persentase } \\
(\%)\end{array}$ \\
\hline 1 & Baik & 6 & 17,6 \\
2 & Cukup & 7 & 20,6 \\
3 & Kurang & 21 & 61,8 \\
\hline Total & 34 & 100 \\
\hline Berdasarkan 4.9. & diketahui & bahwa
\end{tabular}
sebagian besar faktor lingkungan adalah kurang sebanyak 21 orang $(61,8 . \%)$. 
j. Melakukan seks bebas

\begin{tabular}{|c|c|c|c|}
\hline No & $\begin{array}{l}\text { Melakukan } \\
\text { seks bebas }\end{array}$ & Frekuensi & $\begin{array}{c}\text { Persentase } \\
(\%)\end{array}$ \\
\hline 1 & $\begin{array}{c}\text { Tidak seks } \\
\text { bebas }\end{array}$ & 12 & 35,5 \\
\hline 2 & Seks bebas & 22 & 64,7 \\
\hline & Total & 34 & 100 \\
\hline
\end{tabular}

Berdasarkan 4.10 diketahui bahwa sebagian besar pasangan remaja melakukan seks bebas sebanyak 22 orang $(64,7 \%)$.

Untuk faktor keluarga menunjukkan Sebagian besar dengan kategori kurang sejumlah 16 responden $(47,1 \%)$ dan sebagian kecil dengan kategori cukup mempengaruhi pasangan remaja melakukan seks bebas sejumlah 6 responden $(17,6)$. Berdasarkan uji korelasional chi square diperoleh nilai $\rho=$ $0,004<0,05$. Hal ini menunjukkan adanya pengaruh faktor keluarga terhadap pasangan remaja melakukan seks bebas di Kawasan Tretes Kecamatan Prigen Kabupaten Pasuruan.

Untuk Faktor pendidikan seks sebagian besar dengan kategori kurang yaitu sejumlah 19 responden $(55,9 \%)$ dan sebagian kecil dengan kategori cukup mempengaruhi pasangan remaja melakukan seks bebas sejumlah 3 responden $(8,8)$. Berdasarkan uji korelasional chi square diperoleh nilai $\rho=$ $0,002<0,05$. Hal ini menunjukkan adanya pengaruh faktor pendidikan seks terhadap pasangan remaja melakukan seks bebas di Kawasan Tretes Kecamatan Prigen Kabupaten Pasuruan.

Untuk faktor lingkungan sebagian besar dengan kategori kurang sejumlah 18 responden $(52,9 \%)$ dan sebagian kecil dengan kategori baik mempengaruhi pasangan remaja melakukan seks bebas sejumlah 1 responden $(2,9)$. Berdasarkan uji korelasional chi square diperoleh nilai $\rho=0,003<0,05$. Hal ini menunjukkan adanya pengaruh faktor lingkungan terhadap pasangan remaja melakukan seks bebas di Kawasan Tretes Kecamatan Prigen Kabupaten Pasuruan.

\section{Pembahasan}

\section{Faktor keluarga yang mempengaruhi pasangan remaja melakukan sex bebas}

Menurut Panjaitan (2007) Keluarga berantakan adalah keluarga yang cerai berai (berserak-serak) tidak terpelihara dengan baik dan pendidikan anak-anak terlantar disebabkan karena hubungan yang tidak baik antara suami dan isteri serta anak-anaknya. Penyebab utama seks bebas itu, kemungkinan besar karena keluarga dalam kondisi berantakan. Kedua orang tua telah gagal menjadi teladan yang baik bagi anak-anaknya. anak remaja tidak hanya mendengar nasihat dari orang tua saja, tetapi mereka ingin melihat dengan nyata kehidupan orang tua yang sepantasnya untuk diteladani. Biasanya anak-anak belajar dari apa yang mereka alami dan hayati, oleh sebab itu hendaklah orang tua berusaha menjadi teladan yang baik dalam hal kepribadian atas nilai-nilai yang tinggi. Keluarga berantakan terjadi ketika telah terjadi perceraian diantara kedua orang tuanya. Dan hal itu bisa menjadi suatu hal yang menimbulkan penderitaan terhadap anak remajanya. Dan pada akhirnya akan menimbulkan tindakan amoral seks bebas bagi anak remajanya.

Berdasarkan hasil penelitian untuk faktor keluarga menunjukkan 16 respoden dengan kategori kurang mereka melakukan sex bebas, hal ini dikarenakan kurangnya kasih sayang dari keluarga dan kurangnya perhatian dari orang tua bisa membuat para remaja mencari perhatian dari orang lain terutama perhatian dari lawan jenisnya, hal ini biasa membuat para remaja mudah terjerumus ke dalam perilaku seks bebas. Selain itu faktor keluarga yang berantakan seperti sering bertengkar dan perceraian bisa membuat anak remaja merasa depresi dan mencari kesenangan sendiri terutama kesenangan dari lawan jenisnya sehingga terjerumus ke dalam perilaku seks bebas dan sebagian kecil responden dengan 
kategori cukup faktor keluarga melakukan sex bebas hal ini di karenakan oleh faktorfaktor lain di antaranya bekerja merasa punya uang sendiri, adanya calo (makelar vila) dan harga vila yang murah serta aman.

\section{Faktor pendidikan seks yang mempengaruhi pasangan remaja melakukan sex bebas}

Informasi mengenai seks ini, yang paling baik dimulai adalah dalam keluarga. Sebab yang paling awal bertemu dengan anak adalah orang tua dan juga yang paling mengenal anak adalah orang tua. Namun kenyataan yang dilihat sekarang ini adalah sebagian keluarga belum memenuhi tugasnya untuk memberikan pendidikan seks kepada anak-anaknya. Pada waktu kecil maupun remaja, hal ini bukan saja kesalahan keluarga pada masa kini, tetapi juga dilatarbelakangi tradisi zaman dahulu (Panjaitan, 2007). Kurangnya pendidikan seks dalam keluarga, alasan pertama adalah seksual taboos (menganggap seks hal yang kotor dan haram). Alasan kedua, ada sebagian orang tua yang tidak memberikan pendidikan seks terhadap anak-anaknya sebab orang tua itu sendiri beranggapan anaknya akan tahu dengan sendirinya (Panjaitan, 2007).

Berdasarkan hasil penelitian 19 responden dengan kategori kurang faktor pendidikan sex melakukan seks bebas hal ini di karenakan remaja kurang mendapatkan pendidikan seks yang diajarkan oleh orang tua. Ada sebagian orang tua yang masih menganggap bahwa seks merupakan hal yang taboo sehingga tidak berani memberitahukan kepada anak remaja. Orang tua juga tidak memberikan informasi bahwa dengan melakukan seks bebas bisa mengakibatkan kehamilan di luar nikah, terjadinya penyakit menular akibat seksual seperti sifilis, HIV dan sebagian kecil 3 responden dengan kategori cukup faktor pendidikan sex melakukan sex bebas hal itu dikarenakan oleh faktor-faktor lain di antaranya faktor tidak pernah mendapatkan informasi tentang sex ditunjang kurangnya pendidikan agama sejak anak kecil.

\section{Faktor lingkungan yang mempengaruhi pasangan remaja melakukan sex bebas}

Pergaulan bebas adalah hidup berteman tanpa terhalang, terganggu dengan kewajiban, tuntutan, perasaan takut, tidak terikat atau terbatas. Dalam pergaulan bebas ini, seorang remaja merasa bebas pada waktu berteman, tanpa terganggu dengan sesuatu kewajiban yang harus dilakukan, tanpa ada tuntutan dari siapapun, tanpa menimbulkan perasaan takut, tidak terikat atau terbatas dengan siapapun (Panjaitan, 2007). Pengaruh negatif dari sebaya seringkali menjerumuskan seorang remaja ke dalam seks bebas. Misalnya seorang remaja yang menceritakan kepada teman sebayanya tentang nikmatnya berhubungan seks dan keuntungan yang diraihnya dan cara hidup seperti itu, maka teman sebayanya juga pasti terpengaruh dan bahkan terjerumus ke dalam seks bebas (Panjaitan, 2007).

Berdasarkan hasil penelitian 18 responden dengan faktor lingkungan kategori kurang mereka juga melakukan sex bebas hal ini di karenakan lingkungan yang kurang baik membuat remaja melakukan seks bebas. Pada saat ini pergaulan bebas sudah menjadi hal yang biasa bagi para remaja, hal inilah yang sangat berbahaya bagi remaja yang kurang kuat pendidikan agamanya sehingga mudah terjerumus oleh pergaulan temannya yang suka melakukan seks bebas. Selain itu remaja melakukan seks bebas karena diajak oleh temannya untuk menonton film porno sehingga tertarik untuk mencoba apa yang dilihat dalam adegan film porno tersebut yang bisa membuat para remaja dengan mudah melakukan seks bebas untuk mencari kepuasannya dan sebagian kecil 1 
responden dengan kategori baik melakukan sex bebas hal ini dikarenakan oleh faktor-faktor lain di antaranya terpengaruh oleh ajakan teman dan tidak pernah mendapatkan informasi tentang sex.

\section{Simpulan}

1. Faktor keluarga dengan kategori kurang mempengaruhi pasangan remaja melakukan seks bebas sejumlah 16 responden $(47,1 \%)$ dan sebagian kecil dengan kategori cukup mempengaruhi pasangan remaja melakukan seks bebas sejumlah 6 responden $(17,6)$.

2. Faktor pendidikan seks dengan kategori kurang mempengaruhi pasangan remaja melakukan seks bebas sejumlah 19 responden $(55,9 \%)$ dan sebagian kecil dengan kategori cukup mempengaruhi pasangan remaja melakukan seks bebas sejumlah 3 responden $(8,8)$.Faktor pendidikan seks dengan kategori kurang mempengaruhi pasangan remaja melakukan seks bebas sejumlah 19 responden $(55,9 \%)$.

3. Faktor lingkungan dengan kategori kurang mempengaruhi pasangan remaja melakukan seks bebas sejumlah 18 responden $(52,9 \%)$ dan sebagian kecil dengan kategori baik mempengaruhi pasangan remaja melakukan seks bebas sejumlah 1 responden $(2,9)$.

\section{Saran}

a. Bagi masyarakat

Diharapkan masyarakat menanyakan ktp melihat hubungan dan status pasangan pengunjung vila

b. Bagi orang tua

Diharapkan orang tua lebih meningkatkan pengawasan dengan carakomunikasi pada anak-anaknya.

c. Bagi remaja.

Jurnal Ilmu Kesehatan Vol.2 No. 2 Mei 2014
Diharapkan remaja mampu meningkatkan pengetahuan tentang seks bebas dan dampak dari seks bebas

d. Bagi peneliti selanjutnya

Peneliti selanjutnya harus lebih menggali faktor-faktor lain yang mempengaruhi pasangan remaja untuk melakukan sex bebas seperti adanya calo dan didukung harga yang murah

\section{DAFTAR PUSTAKA}

Asrori. 2011. Psikologi Remaja Perkembangan Peserta Didik. Jakarta. Bumi Aksara.

Arikunto, 2010. Prosedur Penelitian. Edisi Baru. Jakarta: Rineka Cipta.

BKKBN, 2013. Data Seks Pra bebas. http://jatim.bkkbn.go.id. Diakses 20/02/2014.

Hidayat. Alimul. 2009. Metode Penelitian Kebidanan dan Teknik Analisa Data. Jakarta. Rineka Cipta.

Notoatmodjo. 2010. Metode Penelitian Kesehatan. Jakarta: PT. Rineka Cipta

Nizam. 2012. Rata-rata wanita pekerja seks (WPS) umur 15 - 23 tahun di Kabupaten Pasuruan. http://news.okezone.com/read. Diakses 20/02/2014.

Nursalam. 2008. Konsep dan Penerapan Metodologi Penelitian Ilmu Keperawatan. Jakarta: Salemba Medika

Panjaitan R. 2007. Solusi Seks Bebas. Jogjakarta : Percetakan Mandiri.

Potter. 2005. Fundamental Keperawatan. EGC. Jakarta.

Sarlito. 2012. Psikologi Remaja. Jakarta. Rajawali Pres 